\title{
Future rainfall and temperature changes in Brazil under global warming levels of $1.5^{\circ} \mathrm{C}$, $2 \circ \mathrm{C}$ and $4 \stackrel{\circ}{\circ} \mathrm{C}$
}

Mudanças futuras de precipitação e temperatura no Brasil a partir dos níveis de aquecimento global de $1,5^{\circ} \mathrm{C}, 2^{\circ}{ }^{\circ} \mathrm{C}$

Diego Jatobá dos Santos ${ }^{\mathrm{a}}$ George Ulguim Pedra ${ }^{b}$ Marcelo Guatura Barbosa da Silvac Carlos Augusto Guimarães Júnior ${ }^{d}$ Lincoln Muniz Alves Gilvan Sampaio $^{f}$ José Antônio Marengo ${ }^{g}$

${ }^{a}$ National Institute for Space Research (INPE), São José dos Campos, SP, Brazil E-mail: diego.santos@inpe.br

${ }^{b}$ National Institute for Space Research (INPE), São José dos Campos, SP, Brazil E-mail: george.pedra@inpe.br

' National Institute for Space Research (INPE), São José dos Campos, SP, Brasil E-mail:marcelo.guatura@inpe.br

${ }^{d}$ National Institute for Space Research (INPE), São José dos Campos, SP, Brazil E-mail: carlos.guimaraesjr@gmail.com

e National Institute for Space Research (INPE), São José dos Campos, SP, Brazil E-mail: lincoln.alves@inpe.br

${ }^{f}$ National Institute for Space Research (INPE), São José dos Campos, SP, Brasil E-mail: gilvan.sampaio@inpe.br

${ }^{g}$ Center for Monitoring and Early Warnings of Natural Disasters - Cemaden, São José dos Campos, SP, Brazil E-mail: jose.marengo@cemaden.gov.br doi:10.18472/SustDeb.v11n3.2020.33933 
Data and results presented in this article were developed under the project of the "Fourth National Communication and Biennial Update Reports of Brazil to the Climate Convention", coordinated by the Ministry of Science, Technology and Innovations, with the support of the United Nations Development Programme and resources of the Global Environment Facility, to which we offer our thanks.

\section{ABSTRACT}

The present study analyzes the impacts of global warming of $1.5 \circ \mathrm{C}, 2{ }^{\circ} \mathrm{C}$, and $4{ }^{\circ} \mathrm{C}$ above pre-industrial levels in the Brazilian territory. Climate change projected among the different global warming levels has been analyzed for rainfall, temperature and extreme climate indices. The projections are derived from the global climate model HadGEM3-A, from the High-End cLimate Impacts and eXtremes (HELIX) international project, from the United Kingdom, forced by sea surface temperature and sea ice concentration of a subset of six CMIP5 (Coupled Model Intercomparison Project phase 5) global climate models and considering the RCP 8.5 (Representative Concentration Pathways) emissions scenario throughout the 21st century. Projections indicate robust differences in regional climate characteristics. These differences include changes: in the minimum and maximum air temperature close to the surface to all the country's regions, in extremes of heat, particularly in northern Brazil, in the occurrence of heavy rainfall (Southern and Southeastern regions), and in the probability of droughts and rain deficits in some regions (Northern and Northeastern Brazil).

Keywords: Climate Change, HELIX, Global Warming, Climate projections, Climate models.

\section{RESUMO}

O presente estudo teve como objetivo analisar, para o território brasileiro, os impactos do aquecimento global de $1,5^{\circ} \mathrm{C}, 2^{\circ} \mathrm{C}$ e 4ㅇ $\mathrm{C}$ acima dos níveis pré-industriais. As mudanças projetadas entre os diferentes níveis de aquecimento global foram analisadas para a precipitação, temperatura e índices de extremos climáticos. As projeções utilizadas são oriundas do modelo climático global HadGEM3-A, derivadas do projeto internacional High-End cLimate Impacts and eXtremes (HELIX), Reino Unido, forçados pela temperatura da superfície do mar e concentração de gelo marinho de um subconjunto de seis modelos climáticos globais do CMIP5 (Coupled Model Intercomparison Project phase 5, em inglês) e considerando o cenário de emissão RCP 8.5 (Representative Concentration Pathways, em inglês) ao longo do século XXI. As projeções indicam diferenças robustas nas características climáticas regionais. Essas diferenças incluem aumentos: na temperatura mínima e máxima do ar próximo a superfície para todas as regiões do país, nos extremos de calor, em particular no norte do país, na ocorrência de chuva intensa (regiões Sul e Sudeste) e na probabilidade de seca e déficits de chuva em algumas regiões (Norte e Nordeste).

Palavras-Chave: Mudança do clima. HELIX. Aquecimento global. Projeções climáticas. Modelos climáticos.

\section{INTRODUCTION}

As a result of natural processes, such as air mass circulation dynamics, ocean currents, volcanic eruptions, among others, the Earth's climate is always changing over time, and numerical modeling is essential to improve knowledge about the climate system's components (atmosphere, land surface, ocean, sea ice, etc.), as well as to list the possible climate change impacts on several important sectors of a given country (such as water, energy, agriculture, etc.).

This modeling's result is one of the main components in studies on climate vulnerability and in the development of measures and strategies for adapting to current and future climate change, serving as a basis for risk and vulnerability analyzes, and thus proposing government mitigation policies (IPCC, 
2018; PBMC, 2013; TNC, 2016). Climate models are essential tools to investigate the climate system's response to many drivers such as sea ice concentration, land-use change, and sea surface temperature, among others. In this regard, they allow projections to be made how the average global temperature can rise in the 21st century and how these changes can affect climate worldwide (FLATO et al., 2013).

To better understand how climate change occurs at the regional level, access to more detailed information on the region to be studied (topography, watersheds, and coastline) is essential. Hence, it is important to increase the spatial resolution of global climate models (GCMs), which in general have a low spatial resolution (about one to two hundred kilometers) due to the high computational cost necessary to perform simulations on a global scale, and/or use downscaling techniques to translate the information provided by GCMs on a more refined spatial scale (MARENGO et al., 2012; FLATO et al., 2013; CHOU et al., 2014; AMBRIZZI et al., 2019).

In Brazil, climate numerical models started at the same time the operational activities of the CPTEC/ INPE began in 1995. Initially, the models were used only to make numerical predictions of time (days) and seasonal climate (seasons) (CAVALCANTI et al., 2002; MARENGO et al., 2003, 2012). However, with the advent of technology and powerful supercomputers, it was possible to make climate projections for South America. The first climate change projections on South America were made using regional climate models (MARENGO and AMBRIZZI, 2006; AMBRIZZI et al., 2007; MARENGO et al., 2009). The first studies were based on results of the following regional models: RegCM3 (GIORGI and MEARNS, 1999; PAL et al., 2007), HadRMP3 (JONES et al., 2004), and Eta-CCS (PISNICHENKO and TARASOVA, 2009) for the period comprising 2070-2100, with high horizontal resolution (50 km) and forced by the HadAM3P global atmospheric model, from the Met Office Hadley Center (MOHC) in the United Kingdom, from GHG emissions scenarios (A2 and B2).

In the past few decades, both GCMs and regional climate models (RCMs) have made significant progress in representing the climate system's components, mainly due to a better representation of their physical processes and phenomena and their interactions (MARENGO et al., 2012). In addition, advances in computer technology have increasingly contributed to the increase in the spatial resolution of climate models, namely the global models used in the HELIX project (40 and $60 \mathrm{~km}$ resolution), whereas, in general, GCMs are typically run at a horizontal resolution of several hundred kilometers.

Improving the models resolution and physical parameterization has led to a more detailed representation of the landscape characteristics, such as mountain ranges, lakes, vegetation types, and soil characteristics, allowing for a better characterization of the hydrological cycle and associated extreme events, as well as a more realistic representation of the regional/local climate, compared to models with lower resolutions (100 - 200 km) (AMBRIZZI et al., 2019; NAUMANN et al., 2018; FLATO et al., 2013; CHOU et al, 2014).

Regarding climate change in international politics, debate on establishing goals to limit global warming to a pre-defined temperature threshold in relation to pre-industrial levels has been discussed since the mid-90s (WBGU, 1995). In 2010, the UNFCCC's $16^{\text {th }}$ Conference of the Parties (COP16), held in Cancun (Mexico), yielded several formal agreements to keep the increase in global average temperature below $2^{\circ} \mathrm{C}$. Later, at the $21^{\text {st }}$ Conference of the Parties (COP21), in Paris (France), a new, more ambitious accord was adopted to strengthen the global response to the threat of climate change and strengthen countries' capacity to deal with the impacts of said changes.

In response to this accord, the Intergovernmental Panel on Climate Change (IPCC) prepared the Special Report on the impacts of global warming of $1.5^{\circ} \mathrm{C}$ above pre-industrial levels (IPCC SR1.5 2018), and the key findings highlight that global warming is likely to reach $1.5^{\circ} \mathrm{C}$ between 2030 and 2052 if the current rate of warming continues, and it is projected that the risk of droughts and floods is more significant at $2^{\circ} \mathrm{C}$ when compared to global warming of $1.5^{\circ} \mathrm{C}$. 
In line with the demands of society and the challenges of the scientific community in understanding the complex climate system, in the past decade, an increasing number of studies have been developed considering the impacts of different Global Warming Levels - GWL - on the regional level (continental domain or part of it), following the example of James and Washington (2013), Vautard et al. (2014), Déqué et al. (2017), Nikulin et al. (2018), Lennard et al. (2018) among others.

In general, these studies show that regional temperature patterns are determined by GWLs and depend heavily on the region - a natural area marked by a specific climate, geological, hydrographic, and biosphere elements time of year considered. In addition, the magnitude of warming of $1.5^{\circ} \mathrm{C}, 2^{\circ} \mathrm{C}$ or above (global average) may be much higher at the local level, leading to more extreme and severe weather conditions than it could be when considering only the global standard.

Several studies in Brazil were made by the Eta-CPTEC regional model (CHOU et al., 2014a; $\mathrm{CHOU}$ et al., 2014b) in line with the HadGEM2-ES and MIROC5 (CMIP5) global models were tailored to GWLs of $1.5^{\circ} \mathrm{C}, 2^{\circ} \mathrm{C}$, and $4^{\circ} \mathrm{C}$ to guide climate vulnerability studies and adaptation measures related to the country's water, energy, food and socio-environmental security under the Fourth National Communication of Brazil (4NC) to the UNFCCC. To that end, the following time slices: 2011-2040, 2041-2070, and $2071-2100$ correspond approximately to GWLs of $1.5^{\circ} \mathrm{C}, 2^{\circ} \mathrm{C}$, and $4^{\circ} \mathrm{C}$, respectively, in the studies of the $4 \mathrm{NC}$.

However, a larger number of studies that seek to quantify the impacts associated with the average increase in global temperature and their magnitude under different GWLs within Brazil's different geographic regions are still necessary and urgent. In this regard, the objective of this work is to analyze the possible changes and their impacts in of terms rainfall and temperature variables in the Brazilian territory under global warming levels of $1.5^{\circ} \mathrm{C}, 2^{\circ} \mathrm{C}$, and $4^{\circ} \mathrm{C}$ above pre-industrial levels, from a set of experiments developed by MOHC within the scope of the High-End cLimate Impacts and eXtremes project (HELIX).

The warming level approach allows for weighing climate change impacts in a more categorical way, under specific global average warming scenarios. Hence, the present work can contribute to vulnerability studies and adaptation to climate change in strategic sectors of the country, as mentioned above.

\section{DATA AND METHODOLOGY}

\subsection{GLOBAL CLIMATE MODEL (HADGEM3-A)}

The present study used the version of the global climate model HadGEM3-A (Global Atmosphere Hadley Center Model, version 3) (WALTERS et al., 2017) developed at the Met Office Hadley Center, in Exeter, United Kingdom, which was part of the HELIX project and Phase 6 of the Coupled Model Intercomparison Project (CMIP6, EYRING et al., 2016). With improvements in its physical parameterizations and inclusion of new features, the referred model, as well as the EC-EARTH3.1 (also used in the HELIX project) of the Swedish Meteorological and Hydrological Institute (SMHI), Sweden, currently represent the state-ofthe-art in terms of representing the global climate system (FLATO et al., 2013).

The simulations obtained by the HadGEM3-A model were carried out in high spatial resolution $(60 \mathrm{~km})$, considering the Sea Surface Temperature (SST) as contour conditions, and concentration of sea ice from a subset of six global models of the CMIP5 (Table 1). Thus, each future climate projection refers to the integration of the HadGEM3-A model with six variants of SST and concentration of sea ice, providing a set of six projections by the end of the 21st century. Detailed information on the main characteristics and references of this subset of models may be obtained in Flato et al. (2013). 
Table 1 | Set of global simulations (realizations) based on the HadGEM3-A model (HELIX project) combined with six CMIP5 models (forcing models). The periods in which the GWLs are reached for each experiment performed are also listed.

\begin{tabular}{cccccc}
\hline $\begin{array}{c}\text { Atmospheric } \\
\text { model }\end{array}$ & $\begin{array}{c}\text { HELIX } \\
\text { realization }\end{array}$ & $\begin{array}{c}\text { CMIP5 forcing } \\
\text { model }\end{array}$ & GWL1.5 & GWL2 & GWL4 \\
\hline HadGEM3-A & r1 & IPSL-CM5A-LR & $2006-2036$ & $2020-2050$ & $2056-2086$ \\
HadGEM3-A & $\mathrm{r} 2$ & GFDL-ESM2M & $2021-2051$ & $2037-2067$ & ${ }^{*}$ \\
HadGEM3-A & $\mathrm{r} 3$ & HadGEM2-ES & $1998-2028$ & $2018-2048$ & $2056-2086$ \\
HadGEM3-A & $\mathrm{r} 6$ & IPSL-CM5A-MR & $2005-2035$ & $2020-2050$ & $2055-2085$ \\
HadGEM3-A & $\mathrm{r} 8$ & MIROC-ESM-CHEM & $2000-2030$ & $2017-2047$ & $2053-2083$ \\
HadGEM3-A & $\mathrm{r} 9$ & ACCESS1-0 & $2012-2042$ & $2024-2054$ & $2066-2096$ \\
\hline
\end{tabular}

* the corresponding model did not reach GWL4 until the end of the projection (2100).

Source: The authors.

Experiments using the HadGEM3-A model considered the RCP 8.5 (Representative Concentration Pathways) emissions scenario, which corresponds to a scenario of high GHG emissions, in which the equivalent $\mathrm{CO}_{2}$ exceeds $1000 \mathrm{ppm}$ (parts per million - by volume) by the end of the 21st century and, with that, the radiative forcing reaches $8.5 \mathrm{~W} / \mathrm{m}^{2}$ (watt per square meter) by the year 2100 , which allows for the assessment of climate change effects under different warming levels (Van VUUREN et al., 2011).

\subsection{GLOBAL WARMING LEVEL (GWL)}

The concept of Global Warming Level (GWL) represents the average variation of the global surface temperature anomaly in relation to the pre-industrial period (1861-1880) (NAUMANN et al., 2018), that is, an increase or decrease in temperature over the years in relation to such period. This approached was used by scientists from the Exeter University and the Met Office Hadley Centre, both in the United Kingdom, in partnership with a number of European institutions, in conducting the HELIX project (RICHARDSON and BRADSHAW, 2017; WYSER et al., 2017).

GWL was defined in this work as the moment when the specific warming value $\left(1.5^{\circ} \mathrm{C}, 2^{\circ} \mathrm{C}\right.$ e $\left.4^{\circ} \mathrm{C}\right)$, calculated in relation to the pre-industrial period, is reached, taking into consideration global averages annual temperature projections. The year in which each GWL was found for the first time was considered as the central year, and the 15 years preceding it and the 15 years following it were added, totaling a period of 31 years for each GWL. Thus, the periods corresponding to each analyzed GWL $\left(1.5^{\circ} \mathrm{C}, 2^{\circ} \mathrm{C}\right.$ and $4^{\circ} \mathrm{C}$ ) in the present study were determined for each of the future simulations, as shown in Table 1. The value of $+0,61^{\circ} \mathrm{C}$ was assumed to be the observed warming value between the pre-industrial period up to the base period used in this work (1981-2010) (HadCRUT4, MORICE et al., 2012).

\subsection{EXTREME CLIMATE INDICES}

The calculation of extreme temperature and rainfall indices (Table 2) was based on the methodologies described in the study by Frich et al. (2002), which have been adopted by the IPCC as of 2007.

Table 2 - Extreme climate indices of maximum temperature (TX) and rainfall (PRCP).

\begin{tabular}{ccc}
\hline Indice & Definition & Unit \\
\hline TX90p & Number of days with TX $>$ 90th percentile & days \\
RX5day & Maximum rainfall accumulated in 5 days & mm \\
CDD & Maximum number of consecutive dry days (PRCP $<1 \mathrm{~mm}$ ) & days \\
\hline
\end{tabular}


For analyzes regarding the maximum extreme temperature indice (TX90p) and the minimum and maximum temperature variables, the daily CPC/NOAA (Climate Prediction Center/ National Oceanic and Atmospheric Administration ${ }^{1}$ ) temperature data set was used. On the other hand, for analyzes involving rainfall and RX5day and CDD indices, the daily rainfall CHIRPS (Rainfall Estimates from Rain Gauge and Satellite Observations ${ }^{2}$ (FUNK et al., 2015) database was used. With regard to the methodology used in calculating the linear trend (section 3.1), a brief description can be obtained from Satyamurty et al. (2010).

\section{RESULTS}

\subsection{CURRENT CLIMATE TREND IN BRAZIL}

Figure 1 shows the trends that occurred in the past few decades (1980-2018) in Brazil for air temperature (maximum and minimum), precipitation and extreme climate indices TX90p, RX5day and CDD for different seasons: summer (December-January-February), autumn (March-April-May), winter (JuneJuly-August), spring (September-October-November), and annual.

A warming trend (about 0.5 - $\mathrm{C}$ per decade) is observed in minimum and maximum temperatures in all regions of the country and in all seasons of the year (Figure 1, columns 1 and 2). The most central sector of the country and the Northern region stand out during the winter and spring seasons where the increments are up to $1^{\circ} \mathrm{C} / \mathrm{dec}$ de. A cooling trend of up to $0.5^{\circ} \mathrm{C} /$ decade is observed, however occasionally in some areas of the country (northwest of the state of Amazonas, east of the state of Mato Grosso, interior of the states of Paraíba and Pernambuco, south of the state of Minas Gerais, east of the states of São Paulo and Rio Grande do Sul), mainly for the minimum temperature during autumn. It is worth noting that the increases observed in recent decades for most of the country are in line with the positive trends in air temperature close to the surface verified in other studies, as in Schwingshackl et al. (2018) and Simmons et al. (2017).

1 | https://www.cpc.ncep.noaa.gov/

2 | https://www.chc.ucsb.edu/data/chirps 

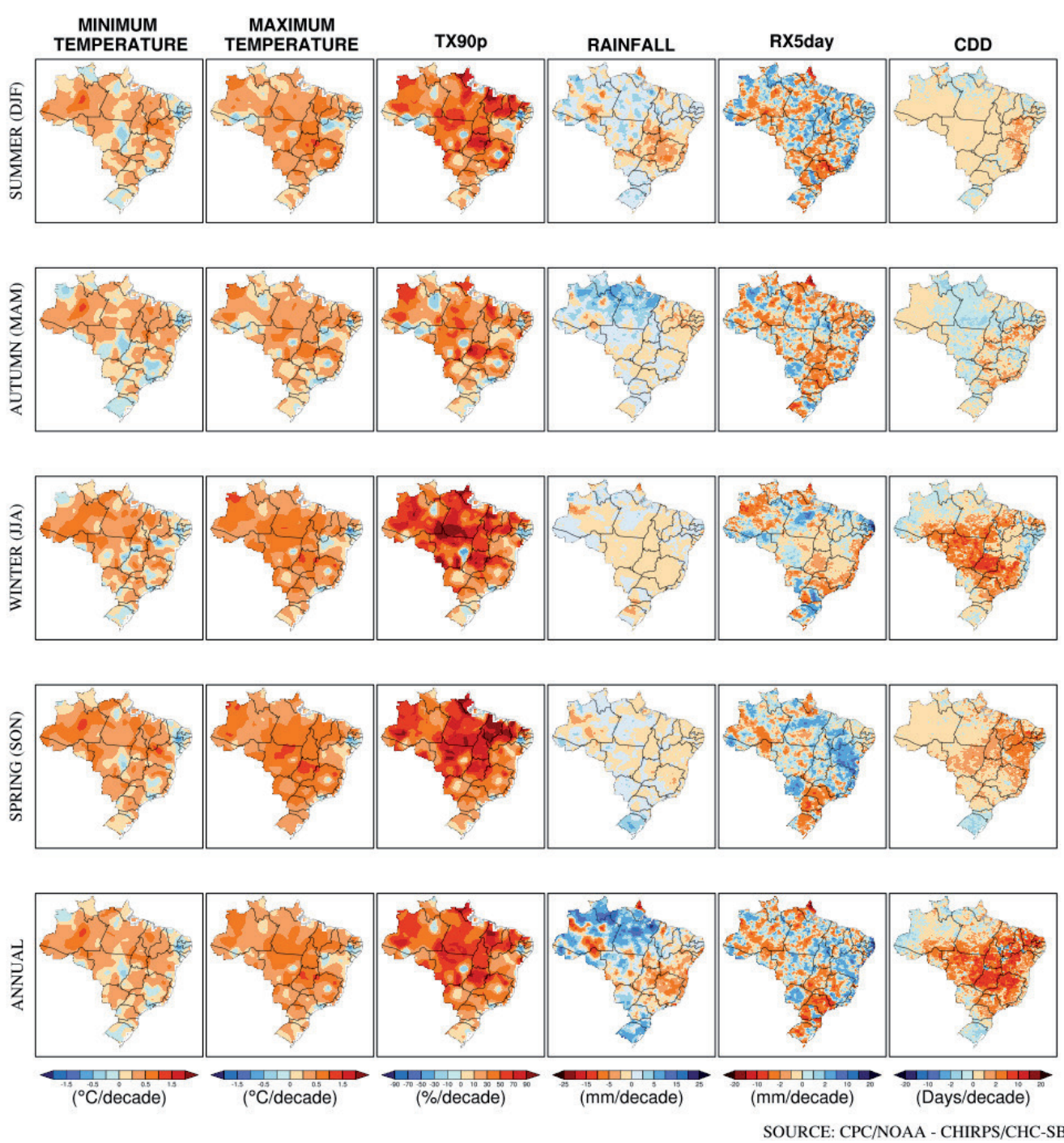

Figure 1 | Linear trend of minimum and maximum temperature (degrees Celsius/decade), of the number of days with maximum temperature above the 90th percentile - TX90p (\%/decade), rainfall (mm/decade), maximum amount of rainfall accumulated in five days - RX5day ( $\mathrm{mm} / \mathrm{decade}$ ) and the maximum number of consecutive dry days - CDD (Days/decade), in the period 1980-2018.

Source: CPC/NOAA and CHIRPS/CHC-SB.

An increase in the number of days with maximum extreme temperature - TX90p (Figure 1, column 3) is also observed along the analyzed period (1980-2018). The increment is above $30 \%$ per decade in practically the whole country, with focus on the central-northern and northern Northeast regions, as it presents significant increases in all time scales, mainly during the winter (JJA) and summer (SON), in which the upward trend is above $90 \%$.

Unlike the temperature trend, that of rainfall (Figure 1, column 4) shows great spatial variability. For the far north of the Northern region, central-east of the Northeastern region and in the Southern region, an increase is observed in the accumulated rainfall totals along seasons. An opposite trend (decrease) can be observed in the southwest of the Northern region, with a total downward trend of about 20 $\mathrm{mm}$ along the past four decades. Taking into account that summer (DJF), climatologically speaking, is the period with the highest volume of rainfall in the Northern region and that during that season this region contributes strongly to the rain regimes in the Center-West and Southeastern regions of the country (SILVA et al ., 2019; ESCOBAR and MATOSO, 2018; REBOITA et al., 2010), this negative trend is also observed in the said regions, mainly in the states of Goiás, Minas Gerais and Espírito Santo, in which this decrease ( $5 \mathrm{~mm} /$ decade) is verified more prominently. 
In brief, throughout all seasons, there is a downward precipitation trend in southern Amazonas, northern Rondônia, in the states of Tocantins and Goiás, and in the southeastern and northeastern regions of the country, and an upward trend in the northern range of the Northern region (mainly in northern Amazonas, Roraima, northern half of Pará and southern Amapá), as well as in most of the Southern region of Brazil.

These behaviors are more evident on an annual scale, in which a more outstanding pattern of the upward trend over the last decades is noted in the extreme north of the Northern region (up to $40 \mathrm{~mm}$ total), in the Southern region (up to $20 \mathrm{~mm}$ ), and in areas of the states of Mato Grosso and Mato Grosso do Sul, however, to a lesser extent. On the other hand, in the other areas of the country, encompassing the states of the Northeastern region, the Southeastern region and the eastern part of the Center-West region, a 20-mm downward trend in rainfall regime is observed between 1980-2018.

With respect to extreme rainfall events (RX5day) (Figure 1, column 5), an annual increment is observed, mainly in the east of the Northeastern region, in the state of Bahia, in the east of the Southeastern region, in most of the Central-West region (with the exception of the state of Goiás) and in interposed areas in the Northern region. In those areas, extreme events total rainfall has increased by 8 to $40 \mathrm{~mm}$ in the past decades. The largest magnitudes are observed in the east of the Northeastern region (with focus on the coastal strip of the states of Rio Grande do Norte, Paraíba, Pernambuco and Alagoas), where a persistence of the upward trend is also observed in seasonal scales, especially during winter (JJA). This suggests that the slightly positive increase in the rainfall trend (Figure 1, column 4) in this part of the Northeastern region during that quarter, as previously mentioned, is possibly associated with these increases in extreme rainfall events.

With respect to maximum number of consecutive dry days trends (Figure 1 column 6), an upward trend is observed mainly in the winter and spring in the south of the Northern region, north and west of the Northeastern region, and in the Central-West and Southeastern regions, indicating a possible intensification of the dry season in those areas, mainly in the region corresponding to the "arc of deforestation" and the Cerrado biome.

The significant increase in the consecutive dry day events trend is also evident in the annual field for these areas, as well as for the Northeastern region as a whole. Therefore, this condition has the potential to further aggravate some socio-environmental issues related to the dry season in those regions, such as the increase in fire outbreaks, soil water deficiency - which in turn implies severe impacts on crop productivity of agricultural commodities exported by Brazil - as well increases risks to human health due to the low humidity of the air during droughts (PBMC, 2013).

It should be pointed out that the time series analyzed in Figure 1 showed statistically significant trends at the $95 \%$ confidence level (Mann-Kendall test) for all variables and indices addressed. This was verified for most of the Brazilian territory (figure not available), except for some areas in the South during autumn and winter, and in the east of the Northeastern region in terms of minimum temperature trends. In addition, the results presented in this section are, in general, in line with previous studies that investigated the physical, dynamic and thermodynamic aspects of the atmospheric and oceanic phenomena (MARENGO et al., 2010; LIEBMANN et al, 2004; CARVALHO et al., 2002).

These studies have emphasized that Brazil's climate is changing, in particular the frequency of extreme rainfall events, which are occurring with a greater intensity (PBMC, 2013), just like temperatures and rainfall variability also seems to be undergoing important changes. These results are corroborated by those by Dunn et. al. (2020), which show increases in the TX90p indice (hot days) and decreases in the TX10p indice (cold nights) throughout Brazil for the period 1901-2018, with the biggest changes occurring in winter - JJA. Authors also show that the R10mm and R95p extreme rain indices show a decrease in the Northeastern region and an increase in the Southern and part of the Southeastern and Center-West regions, and west regions of the Amazon. 


\subsection{PROJECTIONS OF CHANGES IN RAINFALL AND TEMPERATURE}

Figure 2 shows the annual change in rainfall over Brazil, projected for different levels of warming $\left(1.5^{\circ} \mathrm{C}\right.$, $2^{\circ} \mathrm{C}$ and $4^{\circ} \mathrm{C}$ ) and in relation to the 1981-2010 period average (current climate) from the results of the HadGEM3-A model forced with SSTs and sea ice from a subset of CMIP5 models (Table 1). Some similarities are observed among the different warming levels and experiments (a combination of the HadGEM3-A model with forcing models).

The change patterns are somewhat similar, differing only in magnitude, i.e., as the warming level increases, the projected changes become more noticeable. In general, decreased rainfall is projected over much of the Amazon (15-30\%), while in the south of the Southeastern region and in the Southern region an increase is observed, which is more intense in GWL4, with increased rainfall by around $25 \%$ per year. It is also observed that as the GWL increases, the areas of change expand towards the middle of the Brazilian territory. These standards are coherent in the different forcing models, which supports less uncertainty in the projections.
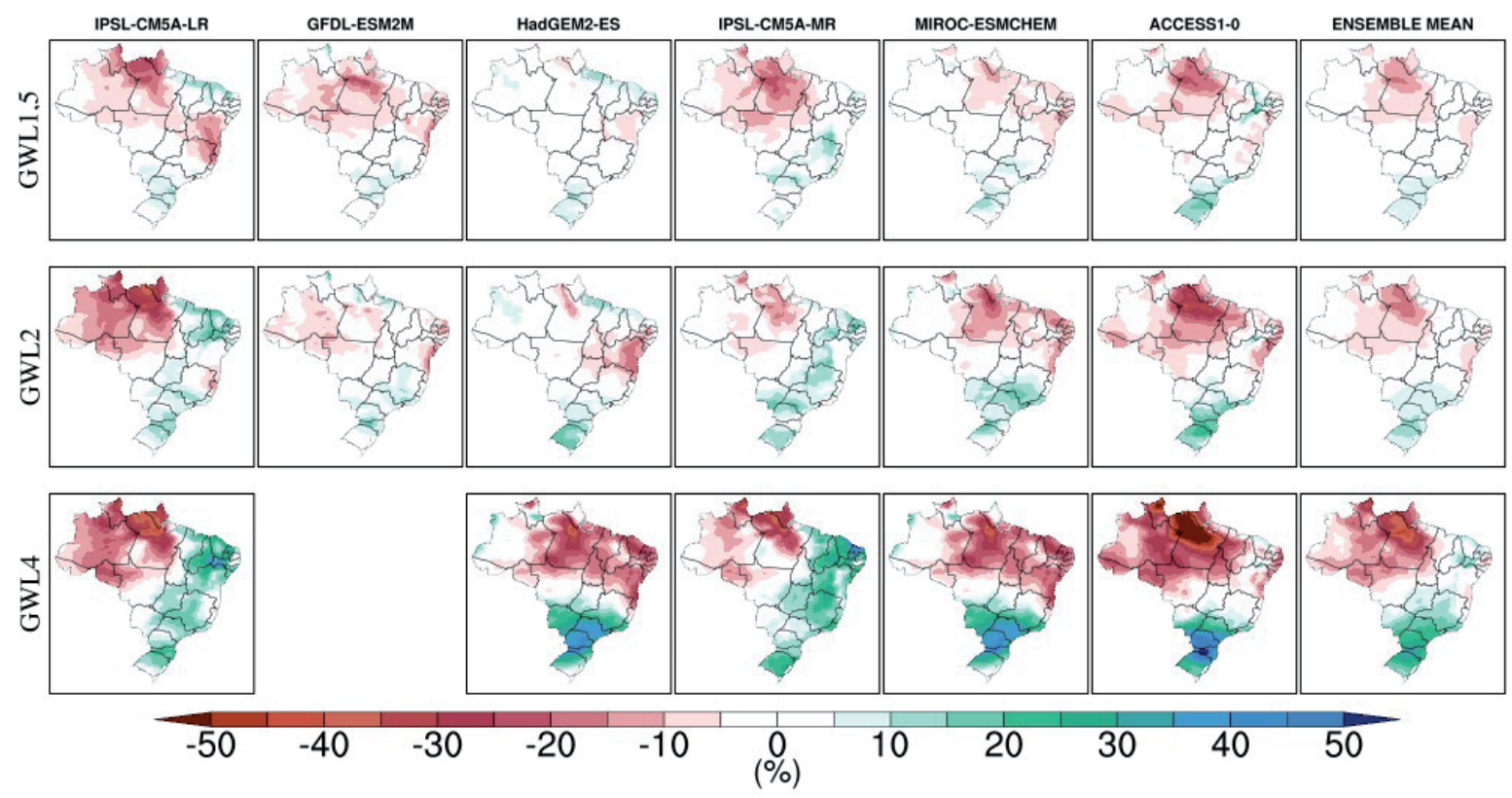

Figure 2 | Rainfall projections: annual rainfall variation (\%) in relation to the baseline period (1981-2010) according to the GWL1.5, GWL2 and GWL4 of each experiment conducted with the HadGEM3-A model.

Source: Authors, based on data from the HELIX Project.

In terms of projections of minimum and maximum temperature changes (Figures 3 and 4, respectively), there is an indication of increased temperature over all regions of Brazil, equal to or higher than the $\mathrm{GWL}$, i.e., it may exceed the predefined $1.5^{\circ} \mathrm{C}, 2^{\circ} \mathrm{C}$ and $4^{\circ} \mathrm{C}$ thresholds.

Most of the analyzed simulations show an expressive increase in the minimum and maximum temperatures for all GWLs addressed, with emphasis on simulations with the IPSL-CM5A-LR, IPSLCM5A-MR e ACCESS1-0 models. On the other hand, smaller increments are presented by the HadGEM2ES e MIROC-ESMCHEM subset. The GFDL-ESM2M model, although also standing out for increased temperatures at GWL 1.5 and $2^{\circ} \mathrm{C}$ levels, did not reach the temperature of $4^{\circ} \mathrm{C}$ in the global average, therefore, projections associated with this model for GWL4 are not presented herein. 

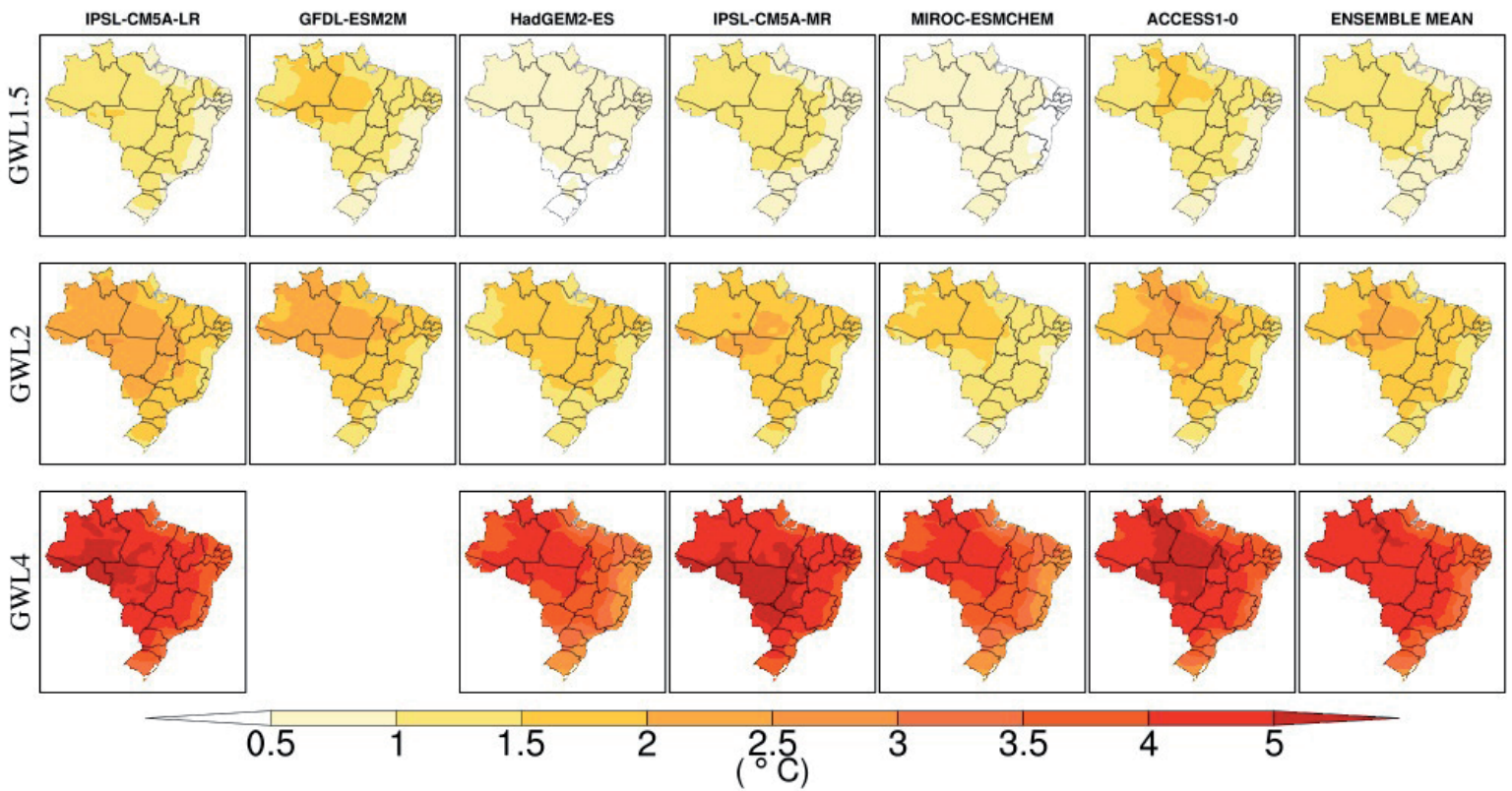

Figure 3 | Temperature projections: variation of the annual minimum average temperature $\left({ }^{\circ} \mathrm{C}\right)$ in relation to the baseline period (1981-2010) according to the GWL1.5, GWL2 and GWL4 of each experiment conducted with the HadGEM3-A model.

Source: Authors, based on data from the HELIX Project.

Upon analyzing Figures 3 and 4 combined, it is possible to identify that the center-south of the Northern region and the Center-West region of Brazil present the greatest possibilities of severe changes in terms of temperature increase, these being the main regions where the minimum and maximum temperature experience expressive increments and in equal proportion, suggesting a drastic change in their climate patterns of temperatures and corroborating with the projections presented in Figure 2, where a significant decrease in rainfall is observed.
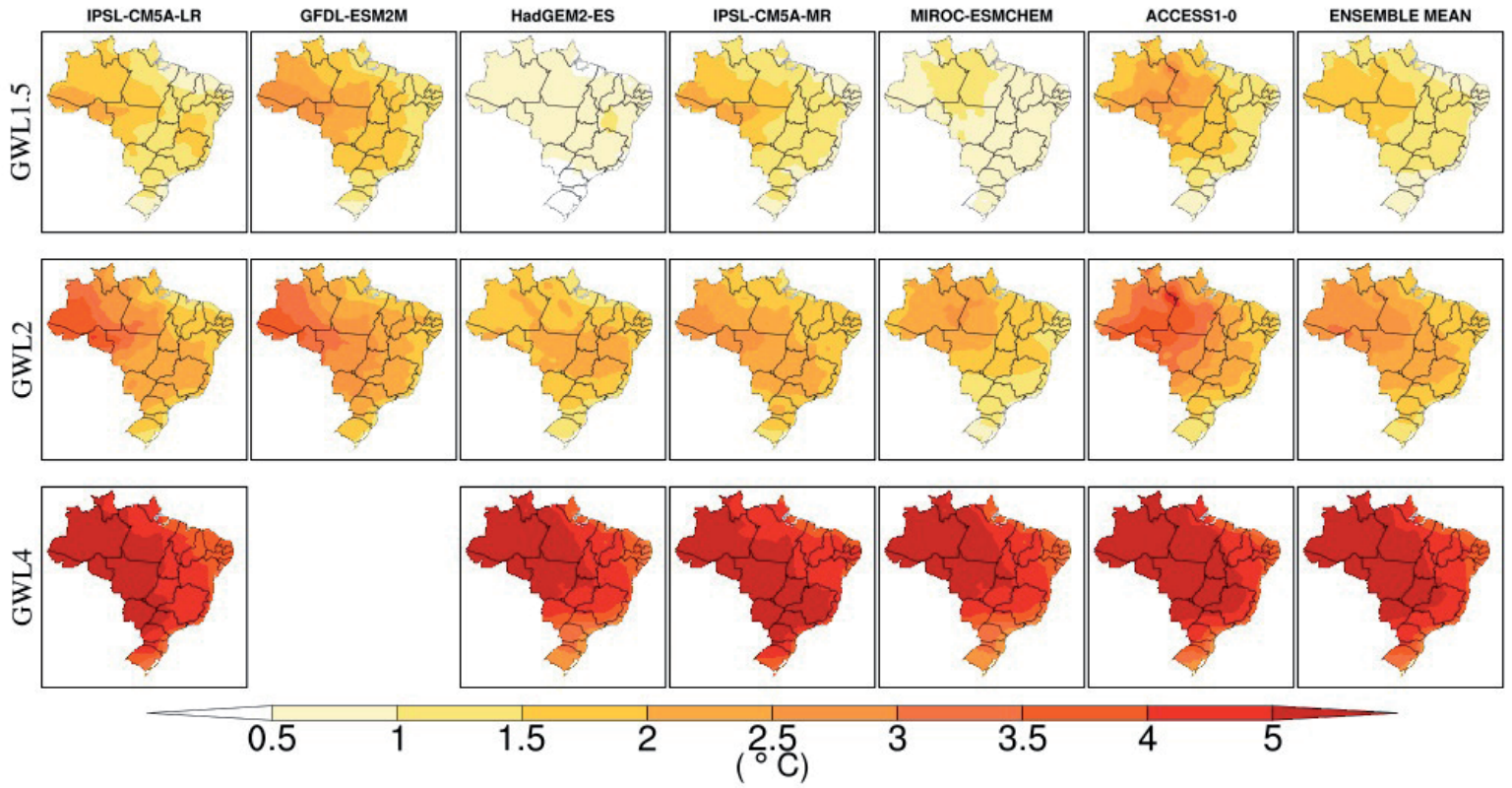

Figure 4 | Temperature projections: variation of the annual maximum average temperature $\left({ }^{\circ} \mathrm{C}\right)$ in relation to the baseline period (1981-2010) according to the GWL1.5, GWL2 and GWL4 of each experiment conducted with the HadGEM3-A model. 
This section analyzed possible climate change in the context of annual average rainfall and temperature. However, it is not simply the changes in average patterns that are relevant to the characterize climate. In this regard, climate extremes can be equally important, as they have a strong influence on natural ecosystems and on human activities such as agriculture, cattle raising, water management, transport, energy and tourism (PBMC, 2013).

\subsection{PROJECTIONS OF CHANGES IN EXTREME CLIMATE EVENTS}

Projections indicate ever-increasing extreme dry events and prolonged droughts (Figure 5), mainly in the north of the Northern and Northeastern regions, with such changes becoming more prominent in GWL4, particularly during winter (Figure 5b), with the states of Amapá, northern Pará and practically the entire Northeastern region showing a significant increase in the number of consecutive dry days. Still on Figure $5 \mathrm{~b}$ and GWL4, there is a divergence among the models on the decrease or increase in the drought period over the Southeastern and Center-West regions. It is worth mentioning that this increase in consecutive dry days (combined with increased temperatures) has the potential to intensify the risk of fires, as well as to change the spatial-temporal rainfall behavior, which, consequently, increases ecosystems vulnerability.

(a) summer (DJF)
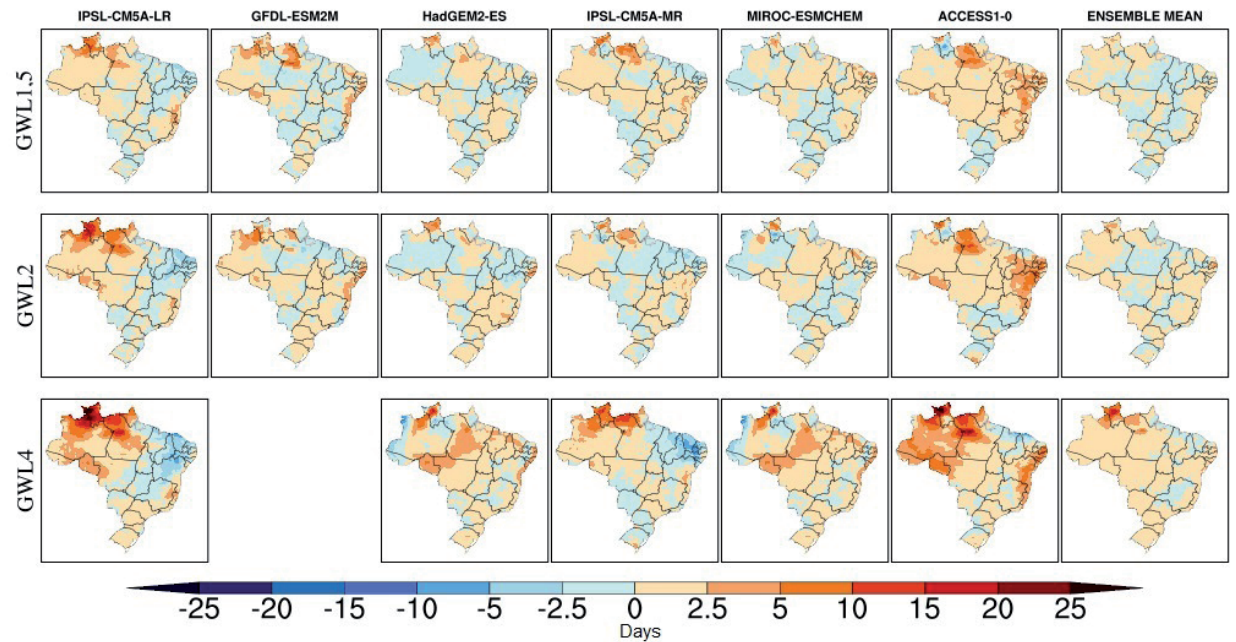

(b) winter (JJA)
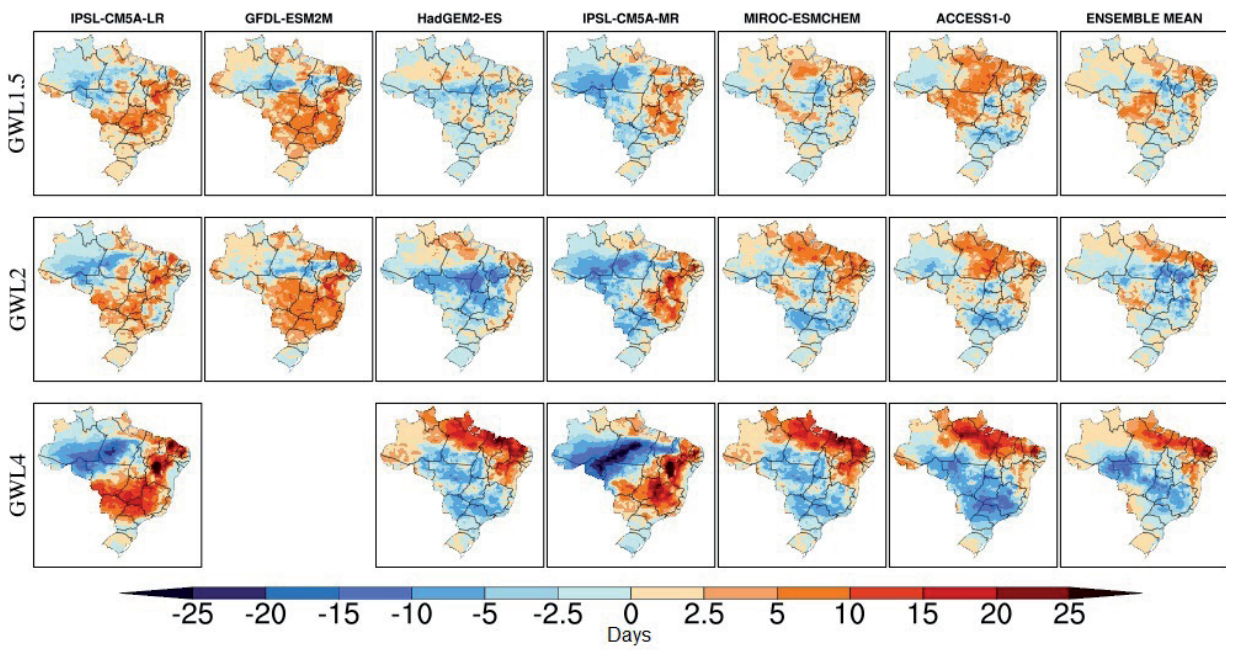

Figure 5 | Climate extreme projections: number of consecutive dry days - CDD in relation to the baseline period (1981-2010) according to the GWL1.5, GWL2 and GWL4 of each experiment conducted with the HadGEM3-A model. 
Although the outcomes presented in Figure 5 indicate a significant increase in prolonged droughts or droughts in the Northeastern region, the indicator shown in Figure 6 provides information on how maximum rainfall will be distributed. During summer (Figure 6a), the state of Amazonas and Pará present a relative drop in the percentage of accumulated rainfall during those extreme rainfall events.

In contrast, in the other areas of the country there is an indication of a significant increase, whose pattern is observed in all GWLs. During winter (figure 6b), these extremes occur all along the Northern and Southern regions. However, there is a greater dispersion among model projection, mainly in GWL 1.5 and 2 for areas in the east of the Center-West and north of the Southeastern regions. In southern Southeast region and in the Southern region of Brazil, the predominance of an increased percentage of intense rainfall is seen in most models, indicating that those regions may present a greater risk of floods, river floods and surface water floods.

(a) summer (DJF)
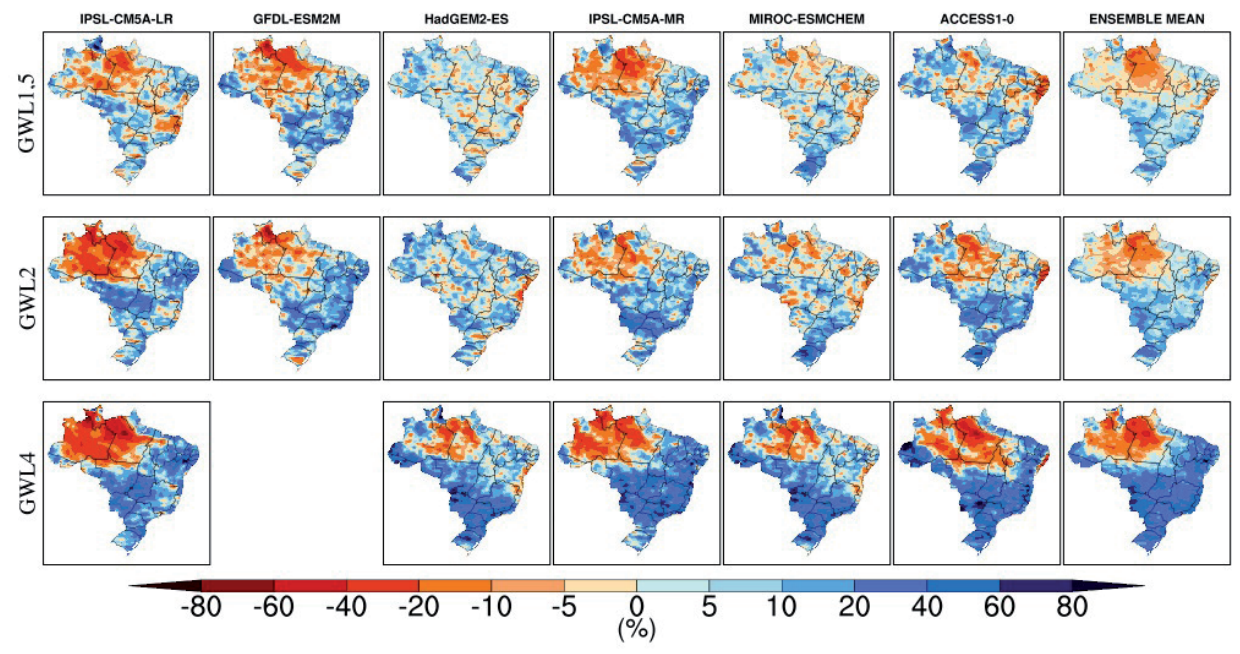

(b) winter (JJA)
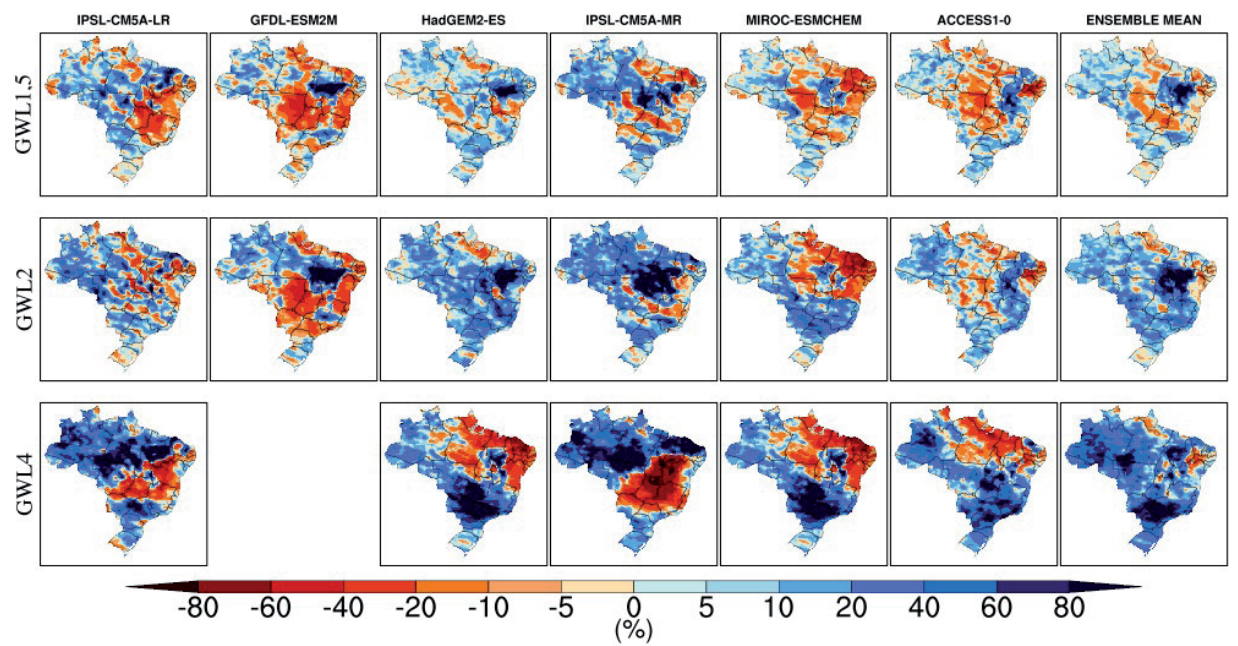

Figure 6 | Climate extremes projections: maximum variation of rainfall accumulated in 5 days - RX5day (\%) in relation to the baseline period (1981-2010) according to GWL1.5, GWL2 and GWL4 in summer (a) and winter (b), for each experiment conducted with the HadGEM3-A model. 
Analyzes of annual minimum and maximum temperatures presented in Figures 3 and 4, respectively, do not establish how the changes associated with increased temperature will be distributed, i.e., it is not clear whether the number of hot days and/or less cold nights will increase. In any case, there is a significant increase in this indicator in the outcomes of hot days projections (Figure 7). Upon analyzing each warming level individually, there is a variation between 15 to 35\% in GWL1.5, mainly in the Northern region in the summer (Figure 7a), and in the Northern and Northeastern regions in the winter (Figura 7b). In GWL2 the spatial pattern is 25 to $65 \%$, strongly focused on the Northern region, while in GWL4 the increase in the number of warm days exceeds $75 \%$ in the said regions for the analyzed seasons.

(a) summer (DJF)
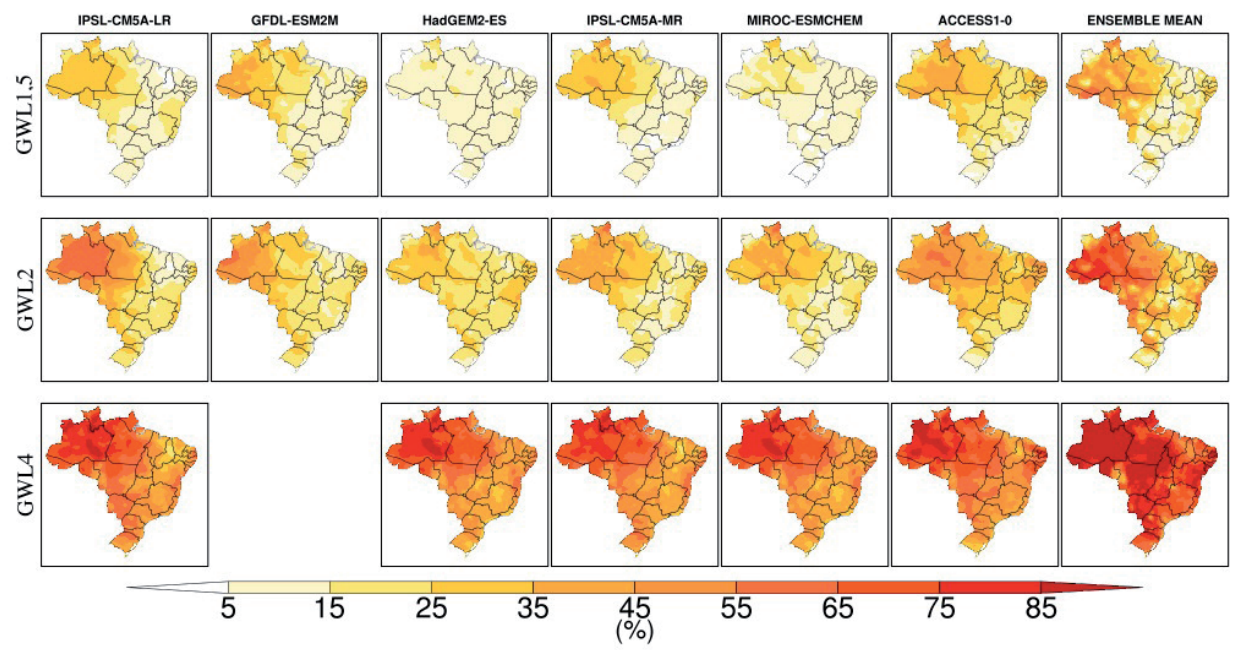

(b) winter (JJA)
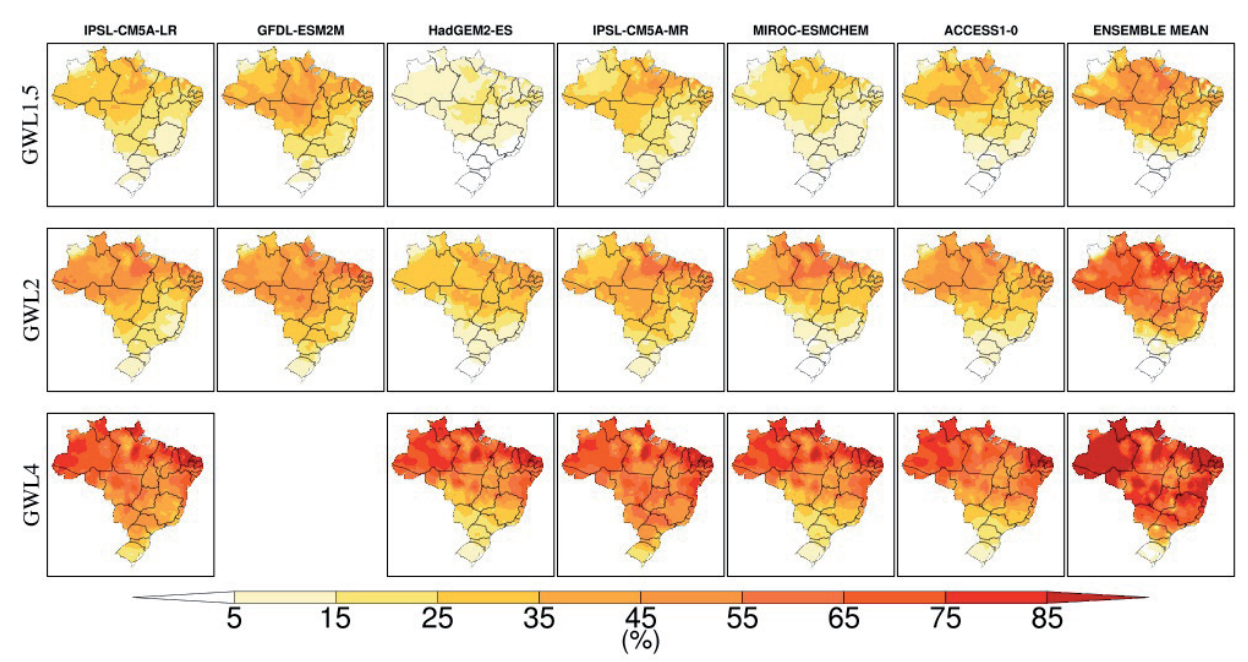

Figure 7 | Climate extremes projections: increased warm days - TX90p (\%) in relation to the baseline period

(1981-2010) according to GWL1.5, GWL2 and GWL4 in summer (a) and winter (b), for each experiment conducted with the HadGEM3-A model.

Source: Authors, based on data from the HELIX Project.

Among the conclusions reported in the Fifth Assessment Report (AR5) of the United Nations Intergovernmental Panel on Climate Change (IPCC, 2013), the one stating that processes that affect the climate can present considerable natural variability, showing variations from recurring to unpredictable at different time and space scales, stands out. Therefore, natural climate variabilities occur over a broad time spectrum, from seasonal scales to tens of thousands of years, resulting in multiple climate 
states, which can be exemplified either by the stages of glacial cycles (tens of thousands of years) or even by the internal variability associated with the El-Niño Oscilação Sul (ENSO) in the inter-annual time scale. Changes in climate's basic state lead to changes in the climate system's the internal variability, controlled by the complex interactions among the components of the terrestrial system (atmosphere, oceans, cryosphere and biosphere) and external forcing (orbital variability and solar activity).

Thus, the relationships between natural variability, external and internal climate forces (such as largescale ocean variability) and their interdependencies, reveal the complexity of the climate system's dynamics, whose understanding is crucial for the assessment of climate change due to anthropogenic contributions (such as greenhouse gas emissions and physical changes in the surface), as well as for predicting future climate. In this sense, IPCC-AR5 confirms that the frequency and intensity of extreme climate events will probably increase (i.e., variability will be intensified) and therefore high spatial and time resolution models must be used to make increasingly more accurate future projections.

Lastly, although it is not appropriate for some purposes to directly compare the outcomes presented herein with those produced by the IPCC with the global climate models participating in CMIP3 and CMIP5, because of their distinct nature (such as, for example, spatial resolution and parameterization schemes) and integration methodology, it is important to highlight that the projections analyzed here are quite consistent with those presented in their reports, as well as climate change studies that used the dynamic downscaling technique, as in Marengo et al. (2012), Solman et al. (2013), Reboita et al. (2014), Chou et al. ( 2014).

\section{CONCLUSION}

This study carried out a country-wide analysis of future rainfall and temperature projections, as well as extreme climate indices associated with those variables. For that purpose, projections were assessed by specific-level average global warming $(\mathrm{GWL})$ of $1.5^{\circ} \mathrm{C}, 2^{\circ} \mathrm{C}$, and $4^{\circ} \mathrm{C}$, using climate simulations sourced from the HadGEM3-A global model (HELIX Project).

The projections point at increased temperature (minimum and maximum) over all regions of Brazil, with this increase being equal to or higher than the GWL analyzed, i.e., regional temperature changes exceed the average global warming at each level addressed $\left(1.5^{\circ} \mathrm{C}, 2^{\circ} \mathrm{C}\right.$, and $\left.4^{\circ} \mathrm{C}\right)$.

The Northern, Center-West and Northeastern regions presented the major changes in terms of temperature increase. In these regions, climate extremes projections of maximum temperature also presented the most severe changes, mainly for the Northern and Northeastern regions. In GWL4, the warming level with the greatest impact, an increase of more than $75 \%$ in the number of hot days is verified in these regions for the two seasons analyzed (summer and winter).

Corcerning to rainfall projections, change patterns are approximately similar among the different warming levels, differing only in magnitude. In this case, as the warming level increases, projected changes become more noticeable. In general, projections show decreased rainfall over much of the Amazon (15-30\%). In the Southern and Southeastern regions an increase is observed, which is more intense in GWL4, with increased annual rainfall by around $25 \%$.

Different projections also point at an increase in extreme drought events, mainly in the north of the Northern region and in the north and semiarid part of the Northeastern region. This is verified in all GWLs, mainly in the winter. In contrast, most simulations project an increase in extreme rainfall events in the south of the Southeastern region and in the Southern region of the country, indicating that those regions are more susceptible to an increased occurrence of floods, river floods and surface water floods. 


\section{ACKNOWLEDGEMENTS}

We would like to thank Dr. Richard Betts, Dr. Chris Jones and the entire HELIX project team and the Met Office Hadley Center, for their help and for making the experiments used in this work available. We would also like to thank the Ministry of Science, Technology and Innovation's Coordination of Climate Change for the institutional support. We also thank UNDP's Project BRA/16/G31 and CNPq Process No. 443807/2018-3.

\section{REFERENCES}

AMBRIZZI, T. et al. Cenários regionalizados de clima no Brasil para o Século XXI: projeções de clima usando três modelos regionais. Ministério do Meio Ambiente (MMA). Secretaria de Biodiversidade e Florestas (SBF). Diretoria de Conservação da Biodiversidade, 2007.

AMBRIZZI, T. et al. The state of the art and fundamental aspects of regional climate modeling in South America. Annals of the New York Academy of Sciences, v. 1436, n. 1, p. 98-120, 2019.

BRASIL. Ministério da Ciência, Tecnologia e Inovações. Terceira comunicação nacional do Brasil à ConvençãoQuadro das Nações Unidas sobre mudança do clima. Setor Uso da Terra, Mudança do Uso da Terra e Florestas. MCT, Brasília, DF, Brasil, p. 79, 2016.

CARVALHO, L. M. V.; JONES, C.; LIEBMANN, B. Extreme precipitation events in southeastern South America and large-scale convective patterns in the South Atlantic convergence zone. Journal of Climate, v. 15, n. 17, p. 23772394, 2002.

CAVALCANTI, I. F. A. et al. Global climatological features in a simulation using the Cptec - COLA AGCM. Journal of Climate, v. 15, n. 21, p. 2965-2988, 2002.

CHOU, S. C. et al. Assessment of climate change over South America under RCP 4.5 and 8.5 downscaling scenarios. American Journal of Climate Change, v. 3, n. 5, p. 512-525, 2014.

$\mathrm{CHOU}, \mathrm{S}$. C. et al. Evaluation of the eta simulations nested in three global climate models. American Journal of Climate Change, v. 3, n. 05, p. 438, 2014.

DÉQUÉ, M. et al. A multi-model climate response over tropical Africa at +2ºc. Climate Services, v. 7, p. 87-95, 2017.

DUNN, R. J. H. et al. Development of an Updated Global Land in Situ-Based Data Set of Temperature and Precipitation Extremes: HadEX3. Journal of Geophysical Research: Atmospheres, v. 125, n. 16, 2020.

ESCOBAR, G. C. J.; MATOSO, V. Zona de Convergência do Atlântico Sul (ZCAS): definição prática segundo uma visão operacional. In: XX CONGRESSO BRASILEIRO DE METEOROLOGIA, 2018, Maceió. Anais... Maceió-AL, 2018.

EYRING, V. et al. Overview of the Coupled Model Intercomparison Project Phase 6 (CMIP6) experimental design and organization. Geoscientific Model Development, v. 9, n. 5, p. 1937-1958, 2016.

FLATO, G. et al. Evaluation of climate models. In: Climate change 2013: the physical science basis. Contribution of Working Group I to the Fifth Assessment Report of the Intergovernmental Panel on Climate Change. Cambridge University Press, 2014. p. 741-866.

FRICH, P. et al. Observed coherent changes in climatic extremes during the second half of the twentieth century. Climate Research, v. 19, n. 3, p. 193-212, 2002.

FUNK, C. et al. The climate hazards infrared precipitation with stations - a new environmental record for monitoring extremes. Scientific Data, v. 2, n. 150066, 2015.

GIORGI, F.; MEARNS, L. O. Introduction to special section: regional climate modeling revisited. Journal of Geophysical Research: Atmospheres, v. 104, n. D6, p. 6335-6352, 1999. 
IPCC. Climate Change 2013: the physical science basis. Contribution of Working Group I to the Fifth Assessment Report of the Intergovernmental Panel on Climate Change. STOCKER, T. F. et al. (Ed.). Cambridge University Press, Cambridge, United Kingdom and New York, NY, USA, 1535 p.

IPCC. Global Warming of $1.5^{\circ} \mathrm{C}$. An IPCC Special Report on the impacts of global warming of $1.5^{\circ} \mathrm{C}$ above preindustrial levels and related global greenhouse gas emission pathways, in the context of strengthening the global response to the threat of climate change, sustainable development, and efforts to eradicate poverty MASSONDELMOTTE, V. et al. (Ed.). In Press.

JAMES, R.; WASHINGTON, R. Changes in African temperature and precipitation associated with degrees of global warming. Climatic change, v. 117, n. 4, p. 859-872, 2013.

JONES, R. G. et al. Generating high resolution climate change scenarios using Precis. Met Office Hadley Centre, Exeter, UK, v. 40, 2004.

LENNARD, C. J. et al. On the need for regional climate information over Africa under varying levels of global warming. Environmental Research Letters, v. 13, n. 6, p. 060401, 2018.

LIEBMANN, B. et al. An observed trend in central South American precipitation. Journal of Climate, v. 17, n. 22, p. 4357-4367, 2004.

MARENGO, J. A.; AMBRIZZI, T. Use of regional climate models in impacts assessments and adaptations studies from continental to regional and local scales. In: Proceedings of, 2006. p. 291-296.

MARENGO, J. A. et al. An intercomparison of observed and simulated extreme rainfall and temperature events during the last half of the twentieth century: part 2: historical trends. Climatic Change, v. 98, n. 3-4, p. 509-529, 2010 .

MARENGO, J. A. et al. Assessment of regional seasonal rainfall predictability using the Cptec/COLA atmospheric GCM. Climate Dynamics, v. 21, n. 5-6, p. 459-475, 2003.

MARENGO, J. A. et al. Development of regional future climate change scenarios in South America using the Eta Cptec/HadCM3 climate change projections: climatology and regional analyses for the Amazon, São Francisco and the Paraná River basins. Climate Dynamics, v. 38, p. 1829-1848, 2012.

MARENGO, J. A. et al. Future change of climate in South America in the late XXI Century: intercomparison of scenarios from three regional climate models (2009) Climate Dynamics. Climate Dynamics. doi:10.1007/s00382009-0721-6, v. 10.

MORICE, C. P. et al. Quantifying uncertainties in global and regional temperature change using an ensemble of observational estimates: the HadCRUT4 data set. Journal of Geophysical Research: Atmospheres, v. 117, n. D8, 2012.

NAUMANN, G. et al. Global changes in drought conditions under different levels of warming. Geophysical Research Letters, v. 45, n. 7, p. 3285-3296, 2018.

NIKULIN, G. et al. The effects of 1.5 and 2 degrees of global warming on Africa in the Cordex ensemble. Environmental Research Letters, v. 13, n. 6, p. 065003, 2018.

PAL, J. S. et al. Regional climate modeling for the developing world: the ICTP RegCM3 and RegCNET. Bulletin of the American Meteorological Society, v. 88, n. 9, p. 1395-1410, 2007.

PBMC. Base científica das mudanças climáticas. Contribuição do Grupo de Trabalho 1 do Painel Brasileiro de Mudanças Climáticas ao Primeiro Relatório da Avaliação Nacional sobre Mudanças Climáticas. AMBRIZZI, T.; ARAUJO, M. (Ed.). Coppe. Universidade Federal do Rio de Janeiro, Rio de Janeiro, RJ, Brasil, 464 p.

PISNICHENKO, I. A.; TARASOVA, T. A. The climate version of the Eta regional forecast model. 2. Evaluation of the Eta CCS model performance against reanalysis data and surface observations. Disponível em: <arXiv preprint arXiv:0901>.1461, 2009. 
REBOITA, M. S. et al. Evidências de Circulação de Brisa Vale-Montanha na Serra da Mantiqueira: Cidade de Itajubá-MG. Ciência e Natura, v. 36, n. 1, p. 61-71, 2014.

REBOITA, M. S. et al. Regimes de precipitação na América do Sul: uma revisão bibliográfica. Revista Brasileira de Meteorologia, v. 25, n. 2, p. 185-204, 2010.

RICHARDSON, K.; BRADSHAW, C. Assessment of the impacts of climate change on national level food insecurity using the Hunger and Climate Vulnerability Index. University of Exeter, 2017.

SATYAMURTY, P. et al. Rainfall trends in the Brazilian Amazon Basin in the past eight decades. Theoretical and Applied Climatology, v. 99, n. 1-2, p. 139-148, 2010.

SCHWINGSHACKL, C.; HIRSCHI, M.; SENEVIRATNE, S. I. Global Contributions of Incoming Radiation and Land Surface Conditions to Maximum Near-Surface Air Temperature Variability and Trend. Geophysical research letters, v. 45, n. 10, p. 5034-5044, 2018.

SILVA, J. P. R.; REBOITA, M. S.; ESCOBAR, G. C. J. Caracterização da Zona de Convergência do Atlântico Sul em Campos Atmosféricos recentes. Revista Brasileira de Climatologia, v. 25, 2019.

SIMMONS, A. J. et al. A reassessment of temperature variations and trends from global reanalysis and monthly surface climatological datasets. Quarterly Journal of the Royal Meteorological Society, v. 143, n. 702, p. 101-119, 2017.

SOLMAN, S. A. et al. Evaluation of an ensemble of regional climate model simulations over South America driven by the ERA-Interim reanalysis: model performance and uncertainties. Climate Dynamics, v. 41, n. 5-6, p. 11391157, 2013.

VUUREN, D. P. van et al. RCP2.6: exploring the possibility to keep global mean temperature increase below $2{ }^{\circ} \mathrm{C}$. Climatic Change, v. 109, n. 1-2, p. 95-116, 2011.

VAUTARD, R. et al. The European climate under a $2^{\circ} \mathrm{C}$ global warming. Environmental Research Letters, v. 9, n. 3, p. 034006, 2014.

WALTERS, D. et al. The Met Office unified model global atmosphere 6.0/6.1 and Jules global land 6.0/6.1 configurations. Geoscientific Model Development, v. 10, n. 4, p. 1487-1520, 2017.

WBGU. Scenario for the derivation of global CO2 reduction targets and implementation strategies. WBGU, Bremerhaven, Germany. 1995.

WYSER, K. et al. Documentation of changes in climate variability and extremes simulated by the Helix AGCMs at the 3 GWLs and comparison in equivalent SST/SIC low-resolution CMIP5 projections. HELIX Project Deliverable 3.1. 2017. 